
carbon combustion catalyst characteristic caused by mixing $\mathrm{Bi}_{2} \mathrm{O}_{3}$ with $\mathrm{Tl}_{2} \mathrm{O}_{3}$

\title{
Susumu Nakayama
}

This study investigated the addition of various oxides to further improve the catalytic characteristics of $\mathrm{Tl}_{2} \mathrm{O}_{3}$, which offers a high carbon combustion catalytic capacity to lower the carbon combustion temperature of $660^{\circ} \mathrm{C}$ by $300^{\circ} \mathrm{C}$. Mixtures of carbon ( 2 wt\%) with composite catalysts comprising 20 wt $\% \mathrm{Tl}_{2} \mathrm{O}_{3}-80 \mathrm{wt} \%$ added oxide were analyzed using $\mathrm{DSC} . \mathrm{Bi}_{2} \mathrm{O}_{3}$ offered the best improvement, where the exothermic peak temperatures for carbon combustion of carbon with various $\mathrm{Tl}_{2} \mathrm{O}_{3}-x$ wt $\% \mathrm{Bi}_{2} \mathrm{O}_{3}$ composites were lower than that of carbon with pure $\mathrm{Tl}_{2} \mathrm{O}_{3}$. Isothermal TG measurements were performed using a mixture of carbon and the $\mathrm{Tl}_{2} \mathrm{O}_{3}-95 \mathrm{wt} \% \mathrm{Bi}_{2} \mathrm{O}_{3}$ composite catalyst, where a $2 \mathrm{wt} \%$ weight loss (i.e. removal of all carbon) was achieved above $230^{\circ} \mathrm{C}$. A porous alumina filter was coated with the composite catalyst and carbon was deposited on the filter surface. The filter was held at constant temperatures under air flow, which confirmed that carbon was completely removed at $230^{\circ} \mathrm{C}$. This study demonstrated the potential for using these composite catalysts in self-cleaning particulate filters to decompose and eliminate fine particulate matter and diesel particulate matter generated from steelworks, thermal power plants, and diesel vehicles simply using the heat of the exhaust gas in a factory flue-gas stack or vehicle muffler.

Carbon-based fine particulate matter with a diameter of less than $2.5 \mu \mathrm{m}$ (PM2.5) is generated from steelworks and thermal power plants that consume large amounts of coal. The environmental pollution associated with PM2.5 has become a major social problem ${ }^{1-3}$. The technologies typically used to eliminate PM2.5 include filtering, where multiple filters of different fineness values are used ${ }^{4,5}$, and electrical removal, where positively or negatively charged fine particle droplets are sprayed ${ }^{6,7}$. However, these methods have serious drawbacks, including the need for regular cleaning and complex systems.

Diesel engines offer high energy efficiency and the suppression of carbon dioxide emission, but generate exhaust gas containing diesel particulate matter (DPM) associated with human health risks and environmental contamination $^{8,9}$. In response, research has aimed to develop carbon combustion catalysts to eliminate DPM exhausted from diesel engines at lower temperatures than the current conventional catalysts ${ }^{10-17}$. For example, $\mathrm{La}_{0.8} \mathrm{Cr}_{0.9} \mathrm{Li}_{0.1} \mathrm{O}_{3}{ }^{10}, \mathrm{CeO}_{2}-\mathrm{ZrO}_{2}-\mathrm{Bi}_{2} \mathrm{O}_{3}{ }^{11}, \mathrm{La}_{0.9} \mathrm{Rb}_{0.1} \mathrm{CoO}_{3}{ }^{13}$, and $\mathrm{CeO}_{2} / \mathrm{Pr}_{4.8} \mathrm{Bi}_{1.2} \mathrm{O}_{11}{ }^{14}$ catalysts have been reported. Exhaust gas from diesel cars can be controlled via the collection and elimination of DPM using a filter, where an oxidation catalyst is generally used. This technology has also been considered for the removal of PM2.5 originating from steelworks and thermal power plants.

Although the combustion temperature for pure carbon has been determined using differential scanning calorimetry (DSC) as $660^{\circ} \mathrm{C}$, this can be reduced to $\sim 500{ }^{\circ} \mathrm{C}$ by adding copper oxide to the carbon ${ }^{18}$. The combustion temperature may be reduced by a further $50^{\circ} \mathrm{C}$ when a complex oxide with rare-earth elements are used $^{19}$. Specifically, a previous study found that the addition of yttrium-manganate led to an exothermic DSC peak at $\sim 430^{\circ} \mathrm{C}$, which resulted in good carbon combustion properties ${ }^{20}$. In addition, a previous report on $\mathrm{Tl}_{2} \mathrm{O}_{3}$ observed explosive carbon combustion at $\sim 300^{\circ} \mathrm{C}$ when $5 \%$ or more carbon was mixed with thallium (III) oxide $\left(\mathrm{Tl}_{2} \mathrm{O}_{3}\right)$ (Fig. 1) ${ }^{21}$. The video of explosive carbon combustion with sparks can be found in Fig. 2 (Video Number-1). It should be noted that $\mathrm{Tl}_{2}^{\mathrm{III}} \mathrm{O}_{3}$ is not poisonous, unlike $\mathrm{Tl}_{2}^{\mathrm{I}} \mathrm{SO}_{4}$ and $\mathrm{Tl}^{\mathrm{I}} \mathrm{NO}_{3}$. The application of $\mathrm{Tl}_{2} \mathrm{O}_{3}$ alone is not realistic because thallium is a rare and expensive metal. Thus, the development of $\mathrm{Tl}_{2} \mathrm{O}_{3}$ composites with other metal oxides is important. 


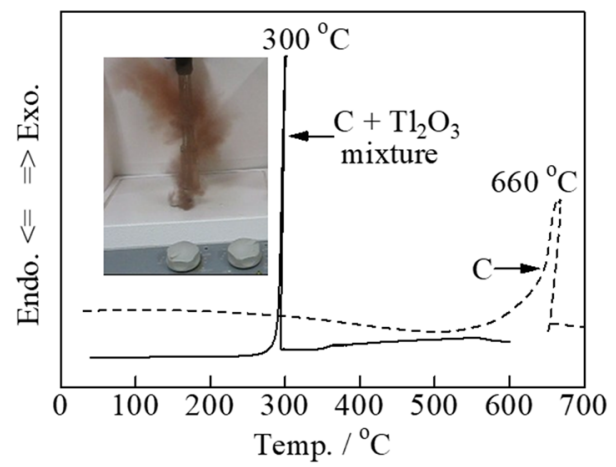

Figure 1. DSC curves of carbon black ( $5 \mathrm{wt} \%$ ) mixed with a pure $\mathrm{Tl}_{2} \mathrm{O}_{3}$ catalyst. Inset is a digital photograph of explosive carbon combustion.

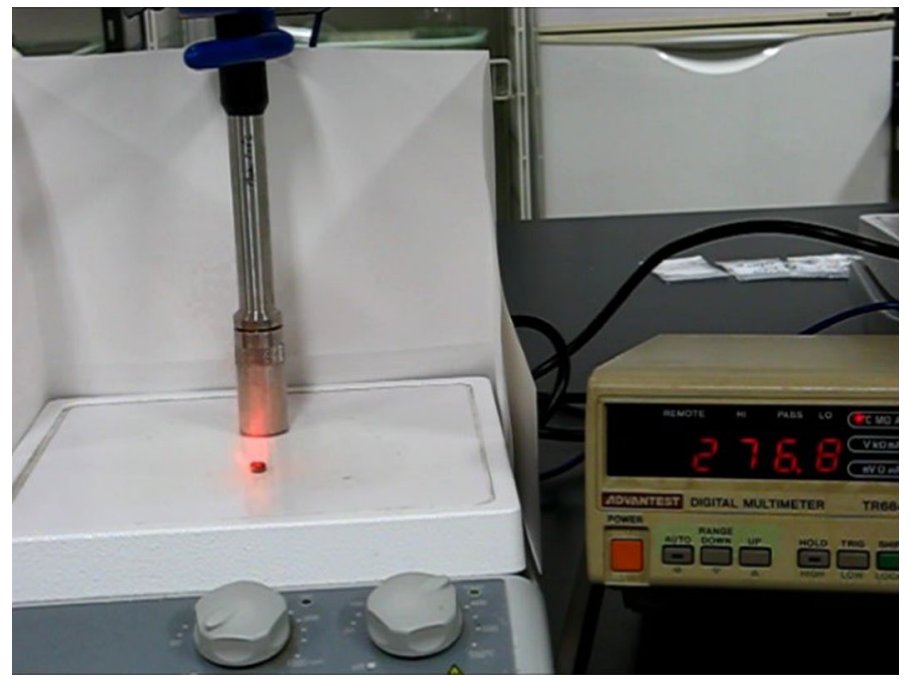

Figure 2. (Video Number-1) Video showing explosive carbon combustion with sparks.

This study aimed to composite $\mathrm{Tl}_{2} \mathrm{O}_{3}$ with other metal oxides that can supply oxygen in the lattice. The composites were evaluated based on their ability to maintain and improve the catalytic properties of $\mathrm{Tl}_{2} \mathrm{O}_{3}$ for low-temperature carbon combustion while reducing the amount of $\mathrm{Tl}_{2} \mathrm{O}$ in the catalyst. Furthermore, the collection of PM2.5 and DPM from exhaust gas was explored using porous ceramic filters coated with the catalytic composites for low-temperature carbon combustion. The filters show promise for applications in the flue-gas stacks of factories or on the muffler of cars. The performance of the self-cleaning type particulate filter for the collection of PM2.5 and DPM was demonstrated experimentally, where the carbon can subsequently be decomposed and removed simply due to the heat of the exhaust gas.

\section{Results and discussion}

Carbon combustion characteristics of the $\mathrm{Tl}_{2} \mathrm{O}_{3}-80$ wt\% added oxide. $\mathrm{Tl}_{2} \mathrm{O}_{3}$ offers excellent carbon combustion properties, and was mixed with both general single oxides, namely $\mathrm{CeO}_{2}, \alpha-\mathrm{Al}_{2} \mathrm{O}_{3}, \mathrm{ZrO}_{2}$, $\mathrm{TiO}_{2}, \mathrm{Bi}_{2} \mathrm{O}_{3}, \mathrm{Pr}_{6} \mathrm{O}_{11}, \mathrm{Cr}_{2} \mathrm{O}_{3}$, and $\mathrm{MnO}_{2}$, and complex oxides with ionic conductivity, namely $\left(\mathrm{Bi}_{2} \mathrm{O}_{3}\right)_{0.75}\left(\mathrm{Y}_{2} \mathrm{O}_{3}\right)_{0.25}$, $\left(\mathrm{CeO}_{2}\right)_{0.8}\left(\mathrm{Gd}_{2} \mathrm{O}_{3}\right)_{0.2}, \mathrm{La}_{9.7} \mathrm{Si}_{6} \mathrm{O}_{26.55}$, and $\mathrm{Pr}_{4.8} \mathrm{Bi}_{1.2} \mathrm{O}_{11}$. Further, $\mathrm{YMnO}_{3}$ was also investigated due to its promising catalytic properties for carbon combustion. The carbon combustion properties of the mixed composite catalysts were improved compared to that of a pure $\mathrm{Tl}_{2} \mathrm{O}_{3}$ catalyst when added to $2 \mathrm{wt} \%$ carbon (Fig. 3). Specifically, the six oxides that led to improved carbon combustion were $\mathrm{Bi}_{2} \mathrm{O}_{3}, \mathrm{Pr}_{6} \mathrm{O}_{11},\left(\mathrm{CeO}_{2}\right)_{0.8}\left(\mathrm{Gd}_{2} \mathrm{O}_{3}\right)_{0.2},\left(\mathrm{Bi}_{2} \mathrm{O}_{3}\right)_{0.75}\left(\mathrm{Y}_{2} \mathrm{O}_{3}\right)_{0.25}$, $\mathrm{La}_{9.7} \mathrm{Si}_{6} \mathrm{O}_{26.55}$, and $\mathrm{Pr}_{4.8} \mathrm{Bi}_{1.2} \mathrm{O}_{11}$, where $\mathrm{Bi}_{2} \mathrm{O}_{3}$ had the largest effect. For comparison, the carbon combustion properties of the $\mathrm{Bi}_{2} \mathrm{O}_{3}, \mathrm{Pr}_{6} \mathrm{O}_{11},\left(\mathrm{CeO}_{2}\right)_{0.8}\left(\mathrm{Gd}_{2} \mathrm{O}_{3}\right)_{0.2},\left(\mathrm{Bi}_{2} \mathrm{O}_{3}\right)_{0.75}\left(\mathrm{Y}_{2} \mathrm{O}_{3}\right)_{0.25}, \mathrm{La}_{9.7} \mathrm{Si}_{6} \mathrm{O}_{26.55}$, and $\mathrm{Pr}_{4.8} \mathrm{Bi}_{1.2} \mathrm{O}_{11}$ catalysts with added to $2 \mathrm{wt} \%$ carbon are shown in Fig. 4. The carbon combustion temperature for all samples was higher than $380^{\circ} \mathrm{C}$. However, the remaining eight oxides did not lead to improved carbon combustion properties $(2 \mathrm{wt} \%$ carbon), namely $\mathrm{CeO}_{2}, \alpha-\mathrm{Al}_{2} \mathrm{O}_{3}, \mathrm{ZrO}_{2}, \mathrm{MnO}_{2}, \mathrm{TiO}_{2}, \mathrm{Cr}_{2} \mathrm{O}_{3},\left(\mathrm{ZrO}_{2}\right)_{0.92}\left(\mathrm{Y}_{2} \mathrm{O}_{3}\right)_{0.08}$, and $\mathrm{YMnO}_{3}$, where the carbon combustion performance was reduced compared to that of pure $\mathrm{Tl}_{2} \mathrm{O}_{3}$ (Fig. 5).

Carbon combustion characteristics of the $\mathrm{Tl}_{2} \mathrm{O}_{3}-\mathrm{Bi}_{2} \mathrm{O}_{3}$ system. Carbon combustion characteristics of $\mathrm{Tl}_{2} \mathrm{O}_{3}-x w t \% \mathrm{Bi}_{2} \mathrm{O}_{3}(x=5-95)$. The addition of $\mathrm{Bi}_{2} \mathrm{O}_{3}$ led to the best carbon combustion properties $(2 \mathrm{wt} \%$ 


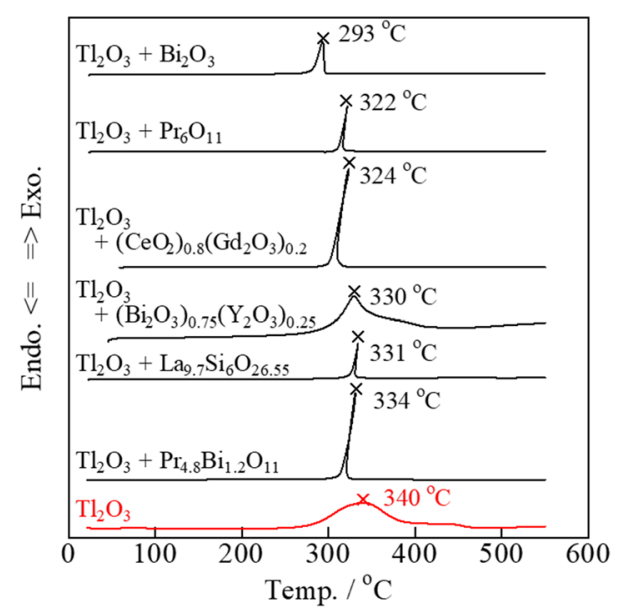

Figure 3. DSC curves of carbon black ( $2 \mathrm{wt} \%$ ) mixed with the various $\mathrm{Tl}_{2} \mathrm{O}_{3}-80 \mathrm{wt} \%$ added oxide composite catalysts.

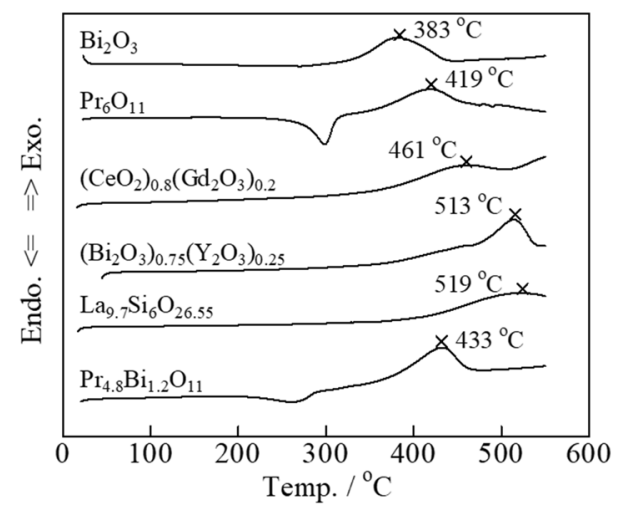

Figure 4. DSC curves of carbon black (2 wt\%) mixed with the various oxide catalysts.

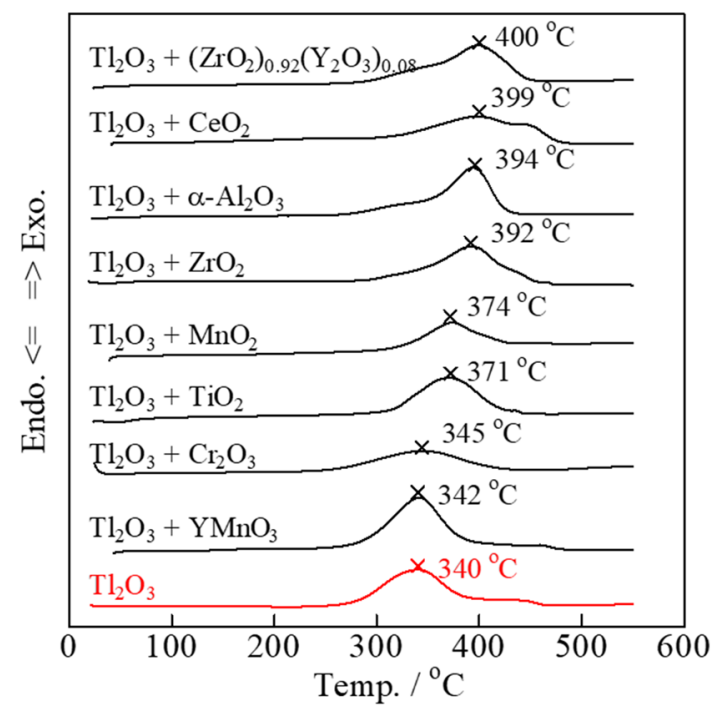

Figure 5. DSC curves of carbon black (2 wt $\%$ ) mixed with the various $\mathrm{Tl}_{2} \mathrm{O}_{3}-80 \mathrm{wt} \%$ added oxide composite catalysts. 


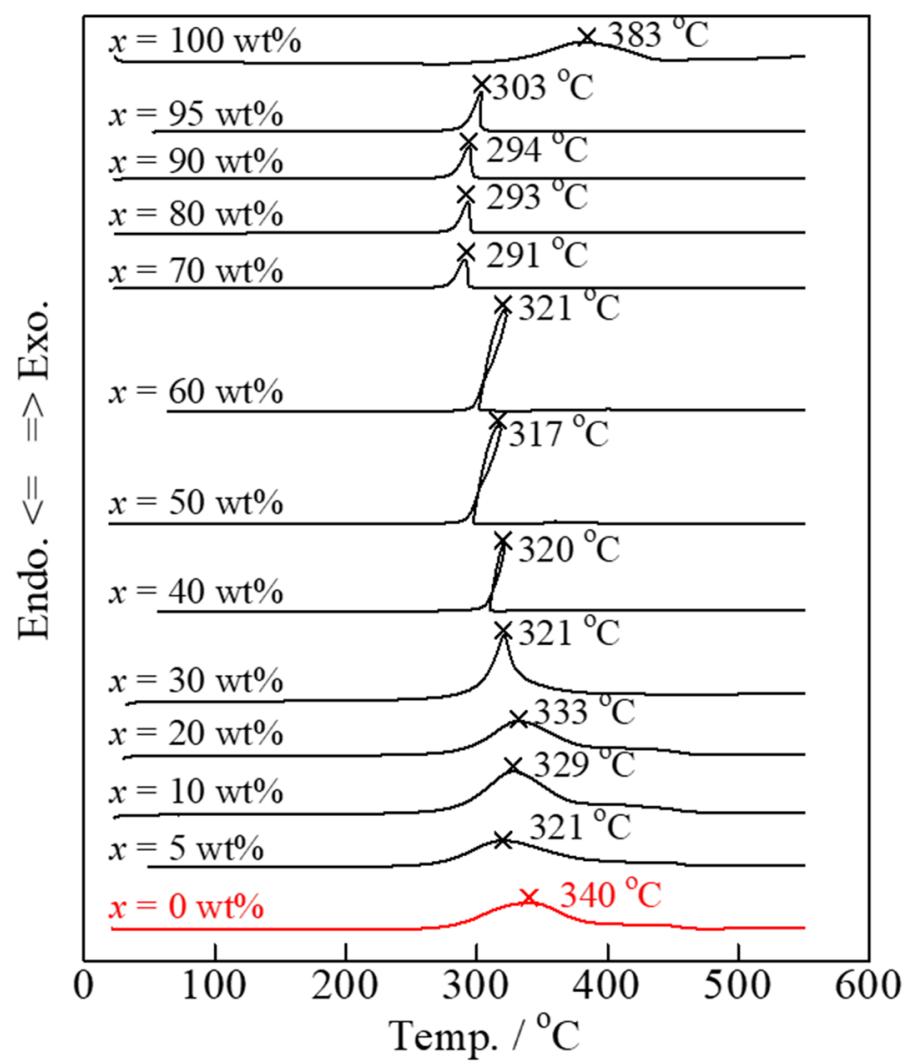

Figure 6. DSC curves of carbon black (2 wt $\%$ ) mixed with the various $\mathrm{Tl}_{2} \mathrm{O}_{3}-x$ wt $\% \mathrm{Bi}_{2} \mathrm{O}_{3}(x=0-100)$ composite catalysts.

carbon) among the various oxides added to $\mathrm{Tl}_{2} \mathrm{O}_{3}$. Thus, the relationship between the proportion of $\mathrm{Bi}_{2} \mathrm{O}_{3}$ in the composite catalyst and the carbon combustion properties was investigated. DSC analysis of the $\mathrm{Tl}_{2} \mathrm{O}_{3}-x$ wt $\%$ $\mathrm{Bi}_{2} \mathrm{O}_{3}(x=0-100)$ composite catalyst mixed with 2 wt $\%$ carbon was compared to $\mathrm{Tl}_{2} \mathrm{O}_{3}-x$ wt $\% \mathrm{Bi}_{2} \mathrm{O}_{3}(x=0-100)$ with no added carbon to determine the carbon combustion performance (Fig. 6). The DSC exothermal peaks of carbon combustion ( $2 \mathrm{wt} \%$ carbon) with pure $\mathrm{Tl}_{2} \mathrm{O}_{3}$ and $\mathrm{Bi}_{2} \mathrm{O}_{3}$ catalysts were observed at 340 and $383{ }^{\circ} \mathrm{C}$, respectively. All of the $\mathrm{Tl}_{2} \mathrm{O}_{3}-x$ wt $\% \mathrm{Bi}_{2} \mathrm{O}_{3}$ composite catalysts exhibited lower exothermal peak temperatures for carbon combustion compared to that of pure $\mathrm{Tl}_{2} \mathrm{O}_{3}$. In particular, the samples with $x$ values of 70, 80, and 90 wt $\%$ exhibited exothermal peak temperatures during carbon combustion ( $2 \mathrm{wt} \%$ carbon) of $300^{\circ} \mathrm{C}$ or less, which was indicative of excellent properties.

Carbon combustion characteristics of thermal-treated $\mathrm{Tl}_{2} \mathrm{O}_{3}-95 w t \% \mathrm{Bi}_{2} \mathrm{O}_{3}$. Applications of carbon combustion catalysts often involve environments associated with the exposure to temperatures of $\sim 500{ }^{\circ} \mathrm{C}$. Carbon $(2 \mathrm{wt} \%)$ was mixed with the $\mathrm{Tl}_{2} \mathrm{O}_{3}-95$ wt $\% \mathrm{Bi}_{2} \mathrm{O}_{3}$ catalyst, and was either left unheated or heat-treated at 200, 300, 400, and $500{ }^{\circ} \mathrm{C}$. DSC analysis revealed minimal changes in the temperature of the exothermal peaks due to carbon combustion (Fig. 7). Thus, heat treatments of $500^{\circ} \mathrm{C}$ or below had a minimal effect on the carbon combustion properties of $\mathrm{Tl}_{2} \mathrm{O}_{3}-95 \mathrm{wt} \% \mathrm{Bi}_{2} \mathrm{O}_{3}$. The formation of new phases in addition to $\mathrm{Tl}_{2} \mathrm{O}_{3}$ and $\mathrm{Bi}_{2} \mathrm{O}_{3}$ was evaluated during XRD analysis of the $\mathrm{Tl}_{2} \mathrm{O}_{3}-95 \mathrm{wt} \% \mathrm{Bi}_{2} \mathrm{O}_{3}$ catalyst after heating at $500{ }^{\circ} \mathrm{C}$ (Fig. 8). All of the XRD peaks observed at $2 \theta$ values of $20^{\circ}$ to $60^{\circ}$ were attributed to $\mathrm{Tl}_{2} \mathrm{O}_{3}$ and $\mathrm{Bi}_{2} \mathrm{O}_{3}$, thus the formation of complex oxides (e.g. $\mathrm{Tl}_{3} \mathrm{BiO}_{3}$ ) was not observed.

Carbon combustion mechanism of the $\mathrm{Tl}_{2} \mathrm{O}_{3}-\mathrm{Bi}_{2} \mathrm{O}_{3}$ system. Thallium(III) oxide $\left(\mathrm{Tl}_{2} \mathrm{O}_{3}\right)$ powder containing 5 $\mathrm{wt} \%$-carbon was placed on a porcelain dish (Nikkato Co., CW-1). When the mixture was gradually heated, explosive reaction (combustion) occurred around $300{ }^{\circ} \mathrm{C}$ and the reaction products were scattered (Fig. 1). A very small amount of brown residue remained on the porcelain dish was subjected to the XRD measurement. The XRD pattern measured immediately after the explosive reaction showed a weak peak attributable to $\mathrm{Tl}_{2} \mathrm{O}$ around $2 \theta=31^{\circ}$ in addition to peaks attributed to $\mathrm{Tl}_{2} \mathrm{O}_{3}$ (Fig. 9(a)), whereas the peak attributable to $\mathrm{Tl}_{2} \mathrm{O}$ disappeared in the XRD pattern measured after further heating of the residue in air at $300{ }^{\circ} \mathrm{C}$ (Fig. $9(\mathbf{b})$ ). As generally known, porcelain dish itself shows no diffraction peak (Fig. 9(c)). In order to investigate the cause of this disappearance, the TG-DTA measurement was performed for $\mathrm{Tl}_{2} \mathrm{O}$ (Kojundo Chemical Lab. Co., Ltd., $98 \%$ purity) in an air stream. Figure 10 shows an exothermic peak with a maximum at $200{ }^{\circ} \mathrm{C}$ resulting in an increase in weight which corresponds to the formation of $\mathrm{Tl}_{2} \mathrm{O}_{3}$ by the oxidation of $\mathrm{Tl}_{2} \mathrm{O}$. In fact, it was confirmed that the sample obtained by igniting the $\mathrm{Tl}_{2} \mathrm{O}$ powder at $200{ }^{\circ} \mathrm{C}$ in a platinum crucible exhibited the XRD pattern of $\mathrm{Tl}_{2} \mathrm{O}_{3}$ and 


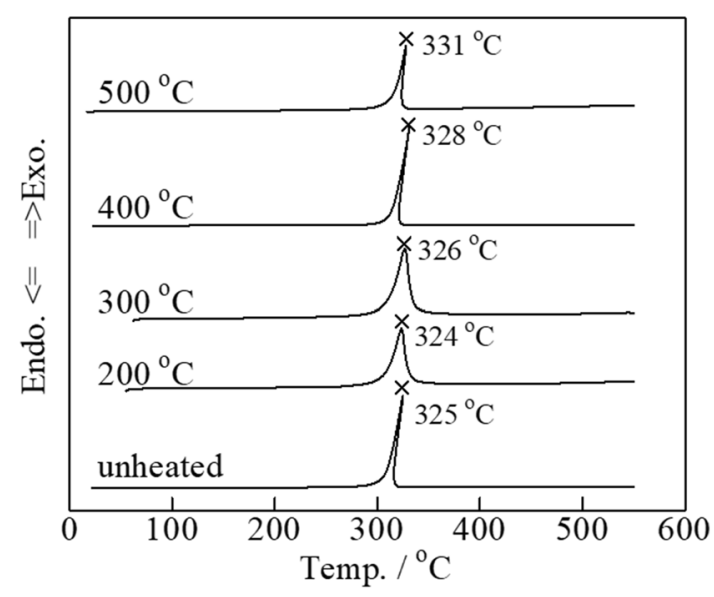

Figure 7. DSC curves of carbon black ( $2 \mathrm{wt} \%$ ) mixed with $\mathrm{Tl}_{2} \mathrm{O}_{3}-95 \mathrm{wt} \% \mathrm{Bi}_{2} \mathrm{O}_{3}$ and either left unheated or heat-treated at $200,300,400$, and $500{ }^{\circ} \mathrm{C}$ for $2 \mathrm{~h}$.

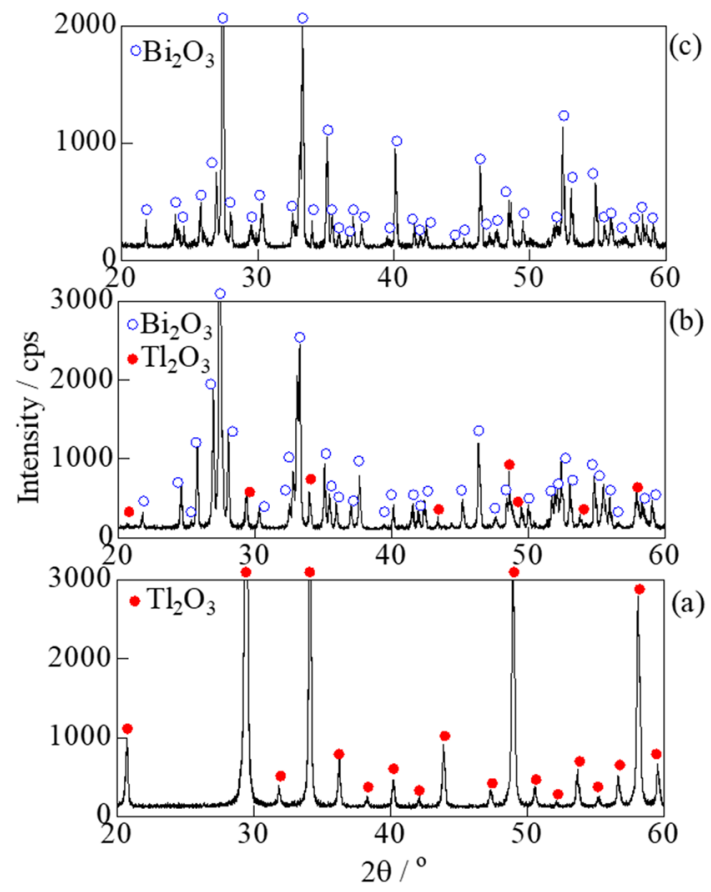

Figure 8. $\mathrm{XRD}$ analysis of (a) $\mathrm{Tl}_{2} \mathrm{O}_{3}$, (b) $\mathrm{Tl}_{2} \mathrm{O}_{3}-95 \mathrm{wt} \% \mathrm{Bi}_{2} \mathrm{O}_{3}$, and (c) $\mathrm{Bi}_{2} \mathrm{O}_{3}$ after heat-treatment at $500{ }^{\circ} \mathrm{C}$ for $2 \mathrm{~h}$.

no peaks attributable to $\mathrm{Tl}_{2} \mathrm{O}$. From these results, the carbon combustion mechanism on $\mathrm{Tl}_{2} \mathrm{O}_{3}$ can be presumed as follows:

$\mathrm{Tl}_{2} \mathrm{O}_{3}+2 \mathrm{C} \rightarrow 2 \mathrm{Tl}_{2} \mathrm{O}+2 \mathrm{CO}$.

$2 \mathrm{CO}+\mathrm{O}_{2} \rightarrow 2 \mathrm{CO}_{2}$.

$\mathrm{Tl}_{2} \mathrm{O}+\mathrm{O}_{2} \rightarrow \mathrm{Tl}_{2} \mathrm{O}_{3}$.

At first, the lattice oxide ions in $\mathrm{Tl}_{2} \mathrm{O}_{3}$ are released for the oxidation of carbon to form $\mathrm{CO}$ and $\mathrm{Tl}_{2} \mathrm{O}$. Then $\mathrm{CO}$ molecules immediately react with the surrounding oxygen at elevated temperature to give $\mathrm{CO}_{2}$ molecules. The $\mathrm{Tl}_{2} \mathrm{O}$ is also oxidized to $\mathrm{Tl}_{2} \mathrm{O}_{3}$ by the oxygen in air at $200{ }^{\circ} \mathrm{C}$ or above $\left(300{ }^{\circ} \mathrm{C}\right.$ in the present experimental condition) as shown in Fig. 10. Thus, $\mathrm{Tl}_{2} \mathrm{O}_{3}$ functions as a combustion catalyst for carbon.

The carbon combustion mechanism of the $\mathrm{Tl}_{2} \mathrm{O}_{3}-\mathrm{Bi}_{2} \mathrm{O}_{3}$ system was proposed. Although the system comprised a smaller proportion of $\mathrm{Tl}_{2} \mathrm{O}_{3}$ compared to $\mathrm{Bi}_{2} \mathrm{O}_{3}$, the lattice oxygen in $\mathrm{Tl}_{2} \mathrm{O}_{3}$ was used for carbon combustion. The lattice defects of oxygen in $\mathrm{Tl}_{2} \mathrm{O}_{3}$ caused by carbon combustion were immediately recovered by the lattice oxygen in $\mathrm{Bi}_{2} \mathrm{O}_{3}$ (Fig. 11). Therefore, the catalytic functioning for carbon combustion was continuously maintained in $\mathrm{Tl}_{2} \mathrm{O}_{3}$. Furthermore, the high oxygen desorption properties of $\mathrm{Bi}_{2} \mathrm{O}_{3}$ likely enhanced the carbon combustion properties of $\mathrm{Tl}_{2} \mathrm{O}_{3}$. SEM observation and EDS mapping ( $\mathrm{Tl}$ and $\mathrm{Bi}$ ) of the $\mathrm{Tl}_{2} \mathrm{O}_{3}-95 \mathrm{wt} \% \mathrm{Bi}_{2} \mathrm{O}_{3}$ powder 


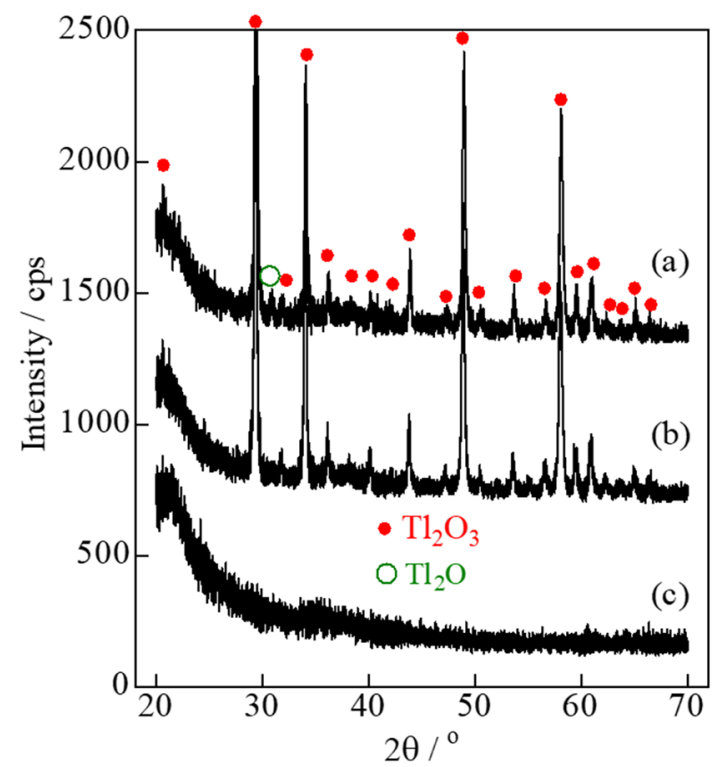

Figure 9. XRD analysis of the surface of porcelain dish. (a) Brown residue after reacting carbon black (5 wt\%) mixed with $\mathrm{Tl}_{2} \mathrm{O}_{3}$ explosively at $300{ }^{\circ} \mathrm{C}$, (b) thermal-treated product after further heating of the brown residue in air at $300{ }^{\circ} \mathrm{C}$, and (c) an unused porcelain dish.

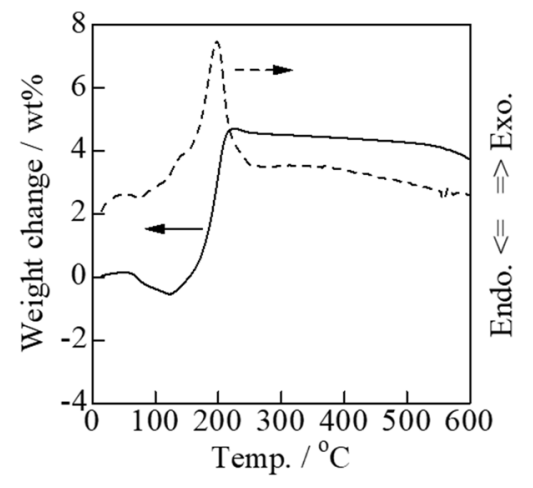

Figure 10. TG-DTA curves of $\mathrm{Tl}_{2} \mathrm{O}$.

(a)

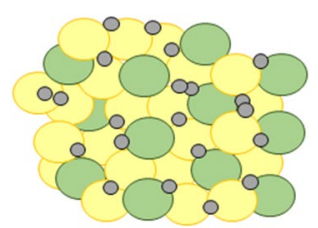

- C

$$
\begin{aligned}
& \mathrm{Tl}_{2} \mathrm{O}_{3} \\
& \mathrm{Bi}_{2} \mathrm{O}_{3}
\end{aligned}
$$

(b)

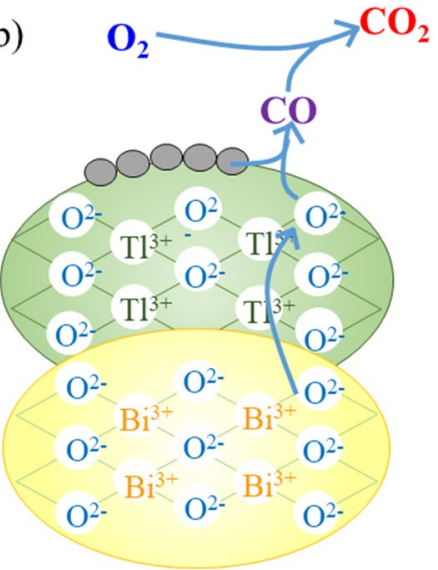

Figure 11. Schematic illustrations of (a) the carbon and $\mathrm{Tl}_{2} \mathrm{O}_{3}-\mathrm{Bi}_{2} \mathrm{O}_{3}$ mixture and (b) the $\mathrm{Tl}_{2} \mathrm{O}_{3}$-modified $\mathrm{Bi}_{2} \mathrm{O}_{3}$-based carbon combustion catalyst and its oxygen transfer mechanism during carbon oxidation. The particle size of carbon is $14 \mathrm{~nm}$ (manufacturer data), and of $\mathrm{Tl}_{2} \mathrm{O}_{3}$ and $\mathrm{Bi}_{2} \mathrm{O}_{3}$ is 0.5 to $3 \mu \mathrm{m}$ (SEM observations). 

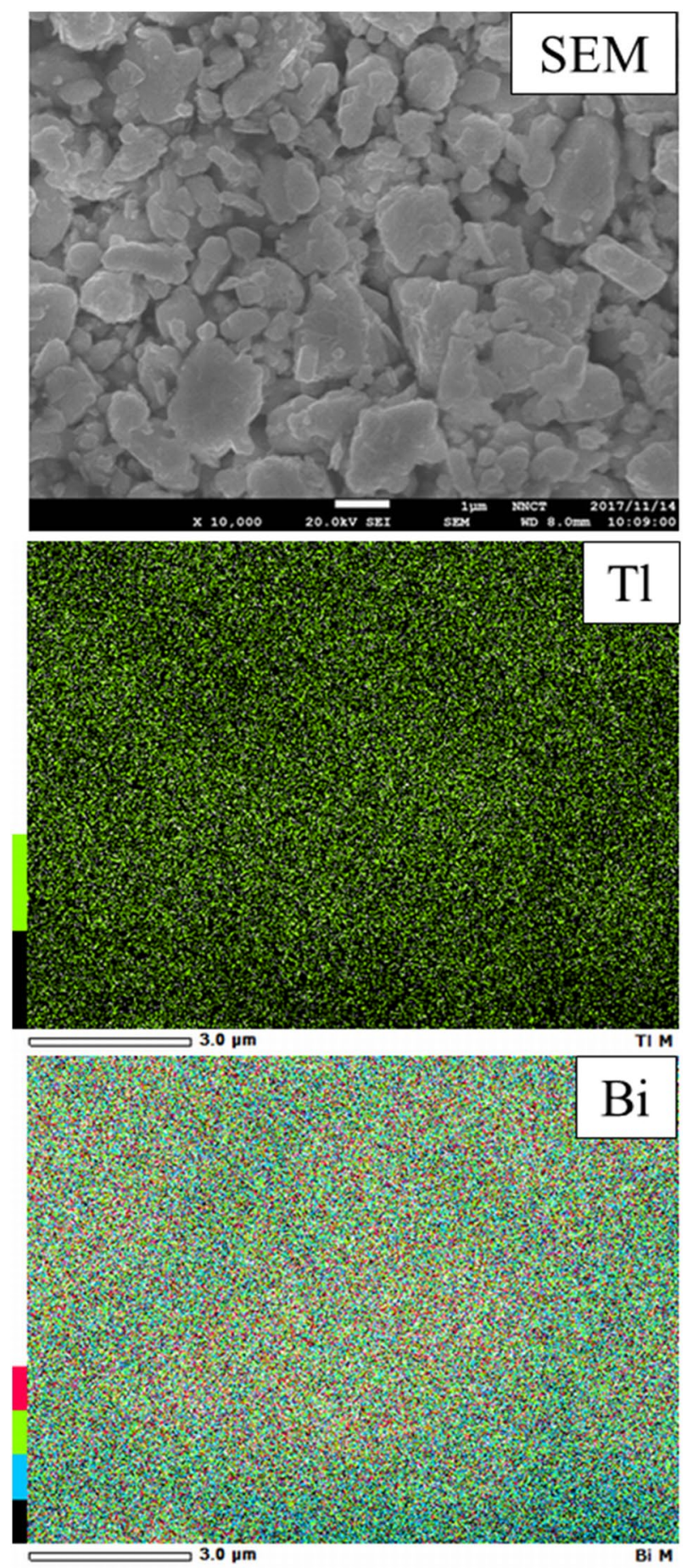

Figure 12. SEM image and EDS elemental mapping images of the $\mathrm{Tl}_{2} \mathrm{O}_{3}-95 \mathrm{wt} \% \mathrm{Bi}_{2} \mathrm{O}_{3}$ composite catalyst.

confirmed that the particle size of the $\mathrm{Tl}_{2} \mathrm{O}_{3}$ and $\mathrm{Bi}_{2} \mathrm{O}_{3}$ powders was $\sim 0.5$ to $3 \mu \mathrm{m}$, which were homogeneously distributed (Fig. 12).

Carbon combustion characteristics of $\mathrm{Tl}_{2} \mathrm{O}_{3}-x$ wt\% $\mathrm{Bi}_{2} \mathrm{O}_{3}(x=95-99.5) . \quad \mathrm{Tl}_{2} \mathrm{O}_{3}$ costs about ten times more than $\mathrm{Bi}_{2} \mathrm{O}_{3}$, thus the cost must be minimized to facilitate practical implementation. The carbon combustion performance was evaluated as the proportion of $\mathrm{Bi}_{2} \mathrm{O}_{3}$ was increased above $95 \mathrm{wt} \%$ (Fig. 13). A large exothermal peak due to carbon combustion was observed up to $99 \mathrm{wt} \%$, but the temperature was slightly higher at $336^{\circ} \mathrm{C}$. These findings indicated that the carbon combustion catalytic function of $\mathrm{Tl}_{2} \mathrm{O}_{3}$ was maintained at levels of only $1 \mathrm{wt} \%$.

Actual carbon combustion is assumed to begin at the rising temperature of the exothermal peak. The temperature at which real carbon combustion initiated and progressed was determined based on isothermal TG analysis of the $\mathrm{Tl}_{2} \mathrm{O}_{3}-95 \mathrm{wt} \% \mathrm{Bi}_{2} \mathrm{O}_{3}$ composite catalyst. The sample was heated in an air stream to either 230, 


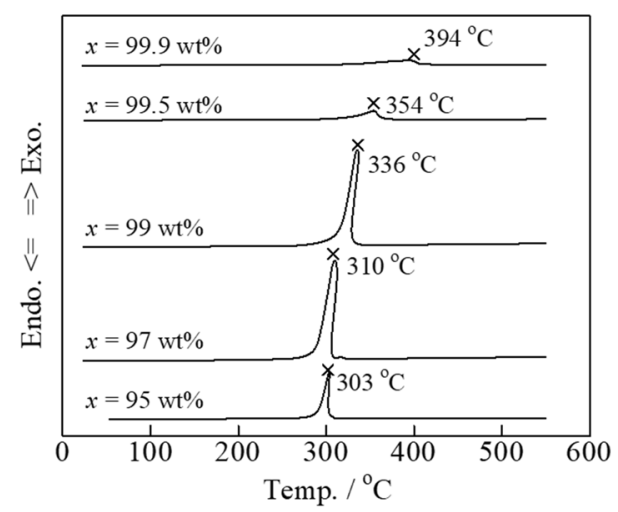

Figure 13. DSC curves of carbon black (2 wt\%) mixed with the various $\mathrm{Tl}_{2} \mathrm{O}_{3}-x$ wt $\% \mathrm{Bi}_{2} \mathrm{O}_{3}(x=95-99.9)$ composite catalysts.

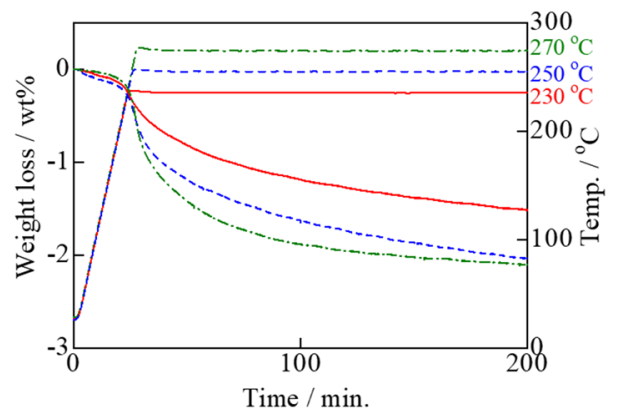

Figure 14. Isothermal $\mathrm{TG}$ analysis of carbon black ( $2 \mathrm{wt} \%)$ mixed with the $\mathrm{Tl}_{2} \mathrm{O}_{3}-95 \mathrm{wt} \% \mathrm{Bi}_{2} \mathrm{O}_{3}$ composite catalyst at constant temperatures of 230,250 , and $270{ }^{\circ} \mathrm{C}$ for $3 \mathrm{~h}$.

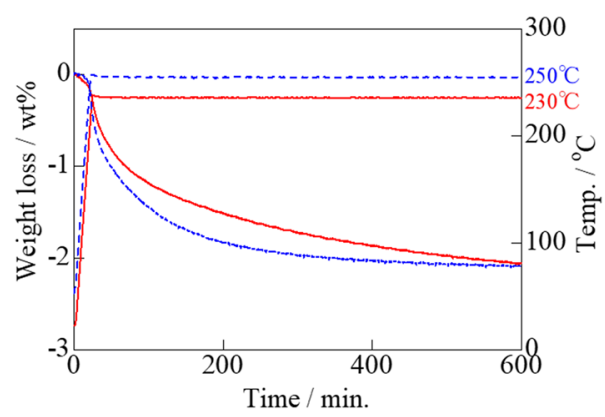

Figure 15. Isothermal TG analysis of carbon black ( $2 \mathrm{wt} \%$ ) mixed with the $\mathrm{Tl}_{2} \mathrm{O}_{3}-95 \mathrm{wt} \% \mathrm{Bi}_{2} \mathrm{O}_{3}$ composite catalyst at constant temperatures of 230 and $250{ }^{\circ} \mathrm{C}$ for $10 \mathrm{~h}$.

250 , or $270^{\circ} \mathrm{C}$, where the weight loss was measured as the sample was held at the respective temperature. The amount of carbon added was $2 \mathrm{wt} \%$, thus the weight loss of $2 \mathrm{wt} \%$ after $3 \mathrm{~h}$ at $270{ }^{\circ} \mathrm{C}$ corresponded to the combustion of all added carbon (Fig. 14). Further, a $2 \mathrm{wt} \%$ weight loss was confirmed at $10 \mathrm{~h}$ when heated at 230 and $250{ }^{\circ} \mathrm{C}$ (Fig. 15). However, only a 1 wt \% weight loss was achieved after heating at $200{ }^{\circ} \mathrm{C}$ for $20 \mathrm{~h}$. These results indicated that the carbon combustion reaction occurred at temperatures higher than $\sim 230^{\circ} \mathrm{C}$.

Carbon combustion using an alumina filter coated with $\mathrm{Tl}_{2} \mathrm{O}_{3}-95 \mathrm{wt} \% \mathrm{Bi}_{2} \mathrm{O}_{3}$. The combustion of carbon on a catalyst-supported alumina filter was demonstrated experimentally using the set-up shown in Fig. 16. Carbon in the form of candle soot was deposited onto the catalyst-supported alumina filter, and the filter was held at constant temperatures of $250,240,230$, and $220^{\circ} \mathrm{C}$ (Fig. 17). Complete removal of the soot via carbon combustion required $\sim 68, \sim 123$, and $\sim 165 \mathrm{~h}$ at 250,240 , and $230{ }^{\circ} \mathrm{C}$, respectively. The soot was not be completely removed at $220^{\circ} \mathrm{C}$ after $216 \mathrm{~h}$. 


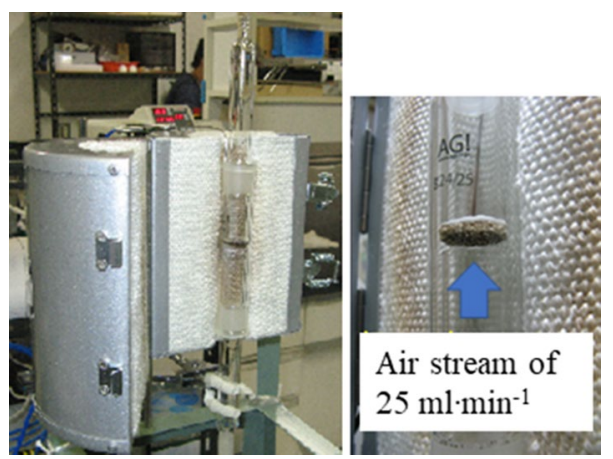

Figure 16. Experimental set-up for evaluating the carbon combustion characteristics of a porous alumina filter coated by the carbon combustion catalyst.

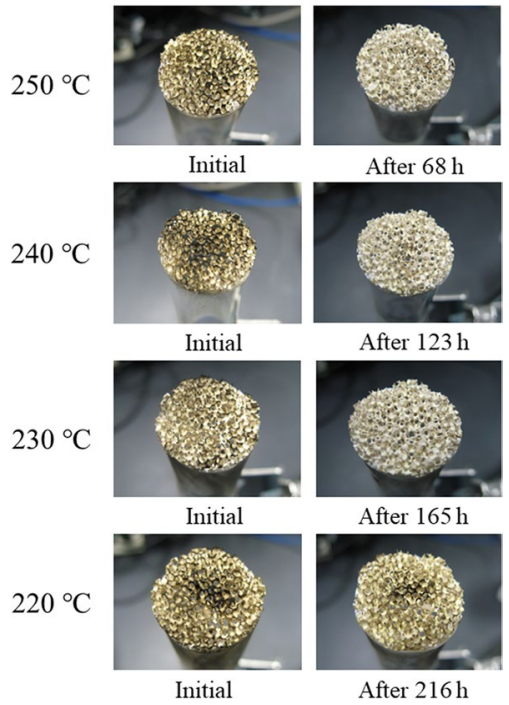

Figure 17. Carbon combustion using the coated porous alumina filter at 220 to $250{ }^{\circ} \mathrm{C}$ in an air stream of $25 \mathrm{ml} \cdot \mathrm{min}^{-1}$.

These results demonstrated that PM2.5 and DPM in exhaust gas could potentially be collected and decomposed using porous ceramic filters coated with the low-temperature $\mathrm{PM}$ combustion $\mathrm{Tl}_{2} \mathrm{O}_{3}-\mathrm{Bi}_{2} \mathrm{O}_{3}$ catalytic system proposed in this study. This is expected to lead to the development of self-cleaning PM filters capable of decomposing and eliminating PM2.5 and DPM simply using the heat of the exhaust gas from a factory flue-gas stack or diesel vehicle muffler.

\section{Conclusions}

The carbon combustion temperature of $660{ }^{\circ} \mathrm{C}$ can be reduced to $300{ }^{\circ} \mathrm{C}$ due to the catalytic effect of $\mathrm{Tl}_{2} \mathrm{O}_{3}$. This excellent carbon combustion catalytic property of $\mathrm{Tl}_{2} \mathrm{O}_{3}$ was further improved by mixing $\mathrm{Tl}_{2} \mathrm{O}_{3}$ with various oxides. Further, a porous ceramic filter was coated with the proposed $\mathrm{Tl}_{2} \mathrm{O}_{3}$-system catalyst to demonstrate its promising catalytic performance. Based on the findings of this study, the following conclusions can be drawn:

1. DSC analysis of the $\mathrm{Tl}_{2} \mathrm{O}_{3}-80 \mathrm{wt} \%$ added oxide composite catalysts in the presence of $2 \mathrm{wt} \%$ carbon revealed that carbon combustion was enhanced by the addition of $\mathrm{Bi}_{2} \mathrm{O}_{3}, \operatorname{Pr}_{6} \mathrm{O}_{11},\left(\mathrm{CeO}_{2}\right)_{0.8}\left(\mathrm{Gd}_{2} \mathrm{O}_{3}\right)_{0.2}$, $\left(\mathrm{Bi}_{2} \mathrm{O}_{3}\right)_{0.75}\left(\mathrm{Y}_{2} \mathrm{O}_{3}\right)_{0.25}, \mathrm{La}_{9.7} \mathrm{Si}_{6} \mathrm{O}_{26.55}$, and $\mathrm{Pr}_{4.8} \mathrm{Bi}_{1.2} \mathrm{O}_{11}$, where $\mathrm{Bi}_{2} \mathrm{O}_{3}$ exhibited a particularly outstanding performance. However, some of the oxides, including $\mathrm{CeO}_{2}, \alpha-\mathrm{Al}_{2} \mathrm{O}_{3}, \mathrm{ZrO}_{2}, \mathrm{MnO}_{2}, \mathrm{TiO}_{2}, \mathrm{Cr}_{2} \mathrm{O}_{3},\left(\mathrm{ZrO}_{2}\right)_{0.92}\left(\mathrm{Y}_{2} \mathrm{O}_{3}\right)_{0.08}$, and $\mathrm{YMnO}_{3}$, compromised the carbon combustion properties of $\mathrm{Tl}_{2} \mathrm{O}_{3}$.

2. The temperature of the exothermal peak due to carbon combustion ( $2 \mathrm{wt} \%$ carbon) during DSC analysis of the $\mathrm{Tl}_{2} \mathrm{O}_{3}-x$ wt $\% \mathrm{Bi}_{2} \mathrm{O}_{3}(x=5-95)$ composite catalysts was reduced compared to that of pure $\mathrm{Tl}_{2} \mathrm{O}_{3}$. The best performance was observed at $x$ values of 70,80 , and $90 \mathrm{wt} \%$, where the temperature of the heat generation peak for carbon combustion was below $300^{\circ} \mathrm{C}$. Furthermore, a large exothermal peak was even observed at an $x$ value of $99 \mathrm{wt} \%$, but the temperature was $~ 336^{\circ} \mathrm{C}$. 
3. Isothermal TG analysis of the $\mathrm{Tl}_{2} \mathrm{O}_{3}-95 \mathrm{wt} \% \mathrm{Bi}_{2} \mathrm{O}_{3}$ composite catalyst with $2 \mathrm{wt} \%$ carbon led to a weight loss of $\sim 2 \mathrm{wt} \%$ at $230^{\circ} \mathrm{C}$ and higher, which was indicative of complete carbon combustion. An alumina filter was coated with the $\mathrm{Tl}_{2} \mathrm{O}_{3}-95 \mathrm{wt} \% \mathrm{Bi}_{2} \mathrm{O}_{3}$ catalyst and exposed to carbon in the form of candle soot. Holding the coated filter at 220 to $250{ }^{\circ} \mathrm{C}$ confirmed that carbon was completely combusted at $230{ }^{\circ} \mathrm{C}$ and higher.

\section{Methods}

Sample preparation. $\quad \mathrm{Tl}_{2} \mathrm{O}_{3}$ and various oxide mixtures. $\mathrm{Tl}_{2} \mathrm{O}_{3}$ powder $(2 \mathrm{~g})$ was wet-mixed with various oxide powders $(8 \mathrm{~g})$, including $\mathrm{CeO}_{2}, \alpha-\mathrm{Al}_{2} \mathrm{O}_{3}, \mathrm{ZrO}_{2}, \mathrm{TiO}_{2}, \mathrm{Bi}_{2} \mathrm{O}_{3}, \mathrm{Pr}_{6} \mathrm{O}_{11}, \mathrm{Cr}_{2} \mathrm{O}_{3}, \mathrm{MnO}_{2},\left(\mathrm{ZrO}_{2}\right)_{0.92}\left(\mathrm{Y}_{2} \mathrm{O}_{3}\right)_{0.08}$, $\left(\mathrm{Bi}_{2} \mathrm{O}_{3}\right)_{0.75}\left(\mathrm{Y}_{2} \mathrm{O}_{3}\right)_{0.25},\left(\mathrm{CeO}_{2}\right)_{0.8}\left(\mathrm{Gd}_{2} \mathrm{O}_{3}\right)_{0.2}, \mathrm{La}_{9.7} \mathrm{Si}_{6} \mathrm{O}_{26.55}, \mathrm{Pr}_{4.8} \mathrm{Bi}_{1.2} \mathrm{O}_{11}$, or $\mathrm{YMnO}_{3}$, in deionized water using a planetary ball mill (Fritsch Co., Pulverisette 6) for $2 \mathrm{~h}$. The mixtures were dried at $100{ }^{\circ} \mathrm{C}$ to obtain composites comprising $\mathrm{Tl}_{2} \mathrm{O}_{3}-80 \mathrm{wt} \%$ added oxide.

$\mathrm{Tl}_{2} \mathrm{O}_{3}$ and $\mathrm{Bi}_{2} \mathrm{O}_{3}$ mixture. Mixtures of $\mathrm{Tl}_{2} \mathrm{O}_{3}$ with varying $\mathrm{Bi}_{2} \mathrm{O}_{3}$ contents (0.5-99.9 wt \%) were prepared from $\mathrm{Tl}_{2} \mathrm{O}_{3}$ (Kojundo Chemical Lab. Co., Ltd., 99.9\% purity) and $\mathrm{Bi}_{2} \mathrm{O}_{3}$ (Kisan Kinzoku Chemicals Co.,Ltd., 99.9\% purity) powders. The $\mathrm{Tl}_{2} \mathrm{O}_{3}$ and $\mathrm{Bi}_{2} \mathrm{O}_{3}$ powder mixtures $(10 \mathrm{~g})$ were wet-mixed in deionized water using a planetary ball mill for $3 \mathrm{~h}$ and dried at $100{ }^{\circ} \mathrm{C}$ to give composites comprising $\mathrm{Tl}_{2} \mathrm{O}_{3}-x$ wt $\% \mathrm{Bi}_{2} \mathrm{O}_{3}(x=0.5-99.9)$.

Characterization. The $\mathrm{Tl}_{2} \mathrm{O}_{3}-80 \mathrm{wt} \%$ added oxide powders were analyzed using X-ray diffraction (XRD, Rigaku Co., MiniFlex II) in the $2 \theta$ range of $20^{\circ}$ to $60^{\circ}$ using $\mathrm{CuK}_{\alpha 1}$. The $\mathrm{Tl}_{2} \mathrm{O}_{3}-95$ wt $\% \mathrm{Bi}_{2} \mathrm{O}_{3}$ powder was observed and analyzed using scanning electron microscopy (SEM, Jeol Ltd., JSM-6510LA) with an energy dispersive spectroscopy (EDS) detector (Jeol Ltd., JED-2300).

The carbon combustion characteristics were evaluated by adding $2 \mathrm{wt} \%$ carbon black (Tokai Carbon Co., Ltd., Toka Black \# 8500/F; average particle size $=14 \mathrm{~nm} ; \mathrm{N}_{2}$ adsorption specific surface area $=290 \mathrm{~m}^{2} \cdot \mathrm{g}^{-1}$ ) to the $\mathrm{Tl}_{2} \mathrm{O}_{3}-80 \mathrm{wt} \%$ added oxide powders and mixing thoroughly in an agate mortar for 1 to $2 \mathrm{~min}$. The mixture $(10 \mathrm{mg})$ was transferred to a platinum pan for differential scanning calorimetry (DSC) analysis (DSC8230; Rigaku Co.) between room temperature and $600^{\circ} \mathrm{C}$ at a heating rate of $10^{\circ} \mathrm{C} \cdot \mathrm{min}^{-1}$ in a $20 \mathrm{~mL} \cdot \mathrm{min}^{-1}$ air stream. The temperature of the DSC exothermic peak was used as the carbon combustion temperature. A mixture of 2 wt $\%$ carbon and $\mathrm{Tl}_{2} \mathrm{O}_{3}-95 \mathrm{wt} \% \mathrm{Bi}_{2} \mathrm{O}_{3}$ powder was prepared in the same manner, and thermogravimetric (TG) analysis (TG8120; Rigaku Co.) was conducted under isothermal conditions for 3 to $20 \mathrm{~h}$ at 200, 230, 250, and $270{ }^{\circ} \mathrm{C}$ at a heating rate of $10^{\circ} \mathrm{C} \cdot \mathrm{min}^{-1}$ in a $20 \mathrm{~mL} \cdot \mathrm{min}^{-1}$ air stream.

A ceramic filter coated with the $\mathrm{Tl}_{2} \mathrm{O}_{3}-95 \mathrm{wt} \% \mathrm{Bi}_{2} \mathrm{O}_{3}$ composite catalyst was prepared. The $\mathrm{Tl}_{2} \mathrm{O}_{3}-95 \mathrm{wt} \% \mathrm{Bi}_{2} \mathrm{O}_{3}$ powder was dispersed in deionized water and coated on a porous $\mathrm{Al}_{2} \mathrm{O}_{3}$ ceramic foam filter (Shinagawa Fine Ceramics Co., Ltd., number of cells: $25-30$ pieces/inch, $\varphi 20 \mathrm{~mm} \times \mathrm{t} 3 \mathrm{~mm}$ ) via a dipping method. The filter was fixed on a glass tube using an inorganic adhesive, and soot was deposited on the outer surface of the filter using a candle flame. The filter was transferred to a mantle heater furnace to evaluate its carbon decomposition and elimination performance. The condition of the soot deposited on the filter was observed every few hours under an air stream of $25 \mathrm{~mL} \cdot \mathrm{min}^{-1}$ from 200 to $270{ }^{\circ} \mathrm{C}$ provided by an air pump.

Received: 27 January 2021; Accepted: 19 March 2021

Published online: 05 May 2021

\section{References}

1. Liang, C.-S., Duan, F.-K., He, K.-B. \& Ma, Y.-L. Review on recent progress in observations, source identifications and countermeasures of PM2.5, Environment International 86, 150-170 https://doi.org/10.1016/j.envint.2015.10.016 (2016).

2. Li, G., Fang, C. \& He, S. The influence of environmental efficiency on PM2.5 pollution: Evidence from 283 Chinese prefecture-level cities, Science of the Total Environment 748, 141549 https://doi.org/10.1016/j.scitotenv.2020.141549 (2020).

3. Xie, X., Ai, H. \& Deng, Z. Impacts of the scattered coal consumption on PM2.5 pollution in China, Journal of Cleaner Production 245, 118922 https://doi.org/10.1016/j.jclepro.2019.118922 (2020).

4. Zhou, F., Diao, Y., Wang, R., Yang, B. \& Zhang, T. Experimental study on PM2.5 removal by magnetic polyimide loaded with cobalt ferrate, Energy and Built Environment 1, 404-409 https://doi.org/10.1016/j.enbenv.2020.04.009 (2020).

5. Yang, X., Pu, Y., Zhang, Y., Liu, X., Li, J., Yuan, D. \& Ning, X. Multifunctional composite membrane based on BaTiO $@ @ P U / P S A$ nanofibers for high-efficiency PM2.5 removal, Journal of Hazardous Materials 391, 122254 https://doi.org/10.1016/j.jhazmat.2020. 122254 (2020).

6. Jaworek, A., Marchewicz, A., Sobczyk, A. T., Krupa, A. \& Czech, T. Two-stage electrostatic precipitators for the reduction of PM2.5 particle emission, Progress in Energy and Combustion Science 67, 206-233 https://doi.org/10.1016/j.pecs.2018.03.003 (2018).

7. Bin, H., Yang, Y., Lei, Z., Ao, S., Cai, L., Linjun, Y. \& Roszak, S. Experimental and DFT studies of PM2.5 removal by chemical agglomeration, Fuel 212, 27-33 https://doi.org/10.1016/j.fuel.2017.09.121 (2018).

8. Chen, C. et al. Study of the characteristics of PM and the correlation of soot and smoke opacity on the diesel methanol dual fuel engine. Appl. Therm. Eng. 148, 391-403. https://doi.org/10.1016/j.applthermaleng.2018.11.062 (2019).

9. Nabi, M. N., Rasul, M. G. \& Brown, R. J. Notable reductions in blow-by and particle emissions during cold and hot start operations from a turbocharged diesel engine using oxygenated fuels. Fuel Process. Technol. 203, 106394. https://doi.org/10.1016/j.fuproc. $2020.106394(2020)$.

10. Russo, N., Fino, D., Saracco, G. \& Specehia, V. Studies on the redox properties of chromite perovskite catalysts for soot combustion. J. Catal. 229, 459-469. https://doi.org/10.1016/j.jcat.2004.11.025 (2005).

11. Masui, T., Minami, K., Koyabu, K. \& Imanaka, N. Synthesis and characterization of new promoters based on $\mathrm{CeO}_{2}-\mathrm{ZrO}_{2}-\mathrm{Bi}_{2} \mathrm{O}_{3}$ for automotive exhaust catalysts. Catal. Today 117, 187-192. https://doi.org/10.1016/j.cattod.2006.05.015 (2006).

12. Krishna, K., Lopez, A. B., Makkee, M. \& Moulijn, J. A. Potential rare earth modified $\mathrm{CeO}_{2}$ catalysts for soot oxidation: I. Characterisation and catalytic activity with $\mathrm{O}_{2}$, Applied Catalysis B: Environmental 75, 189-200 https://doi.org/10.1016/j.apcatb.2007.04. 010 (2007).

13. Russo, N., Furfori, S., Fino, D., Saracco, G. \& Specchia, V. Lanthanum cobaltite catalysts for diesel soot combustion. Appl. Catal. B 83, 85-95. https://doi.org/10.1016/j.apcatb.2008.02.006 (2008). 
14. Harada, K., Oishi, T., Hamamoto, S. \& Ishihara, T. Lattice oxygen activity in Pr- and La-doped CeO $\mathrm{O}_{2}$ for low-temperature soot oxidation. The Journal of Physical Chemistry C 118, 559-568. https://doi.org/10.1021/jp410996k (2014).

15. Wang, L., Fang, S., Feng, N., Wan, H. \& Guan, G. Efficient catalytic removal of diesel soot over $\mathrm{Mg}$ substituted $\mathrm{K} / \mathrm{La}_{0.8} \mathrm{Ce}_{0.2} \mathrm{CoO}_{3}$ perovskites with large surface areas, Chemical Engineering Journal 293, 68-74 https://doi.org/10.1016/j.cej.2016.02.038 (2016).

16. Lee, C., Shul, Y.-G. \& Einaga, H. Silver and manganese oxide catalysts supported on mesoporous $\mathrm{ZrO}_{2}$ nanofiber mats for catalytic removal of benzene and diesel soot. Catal. Today 281, 460-466. https://doi.org/10.1016/j.cattod.2016.05.050 (2017).

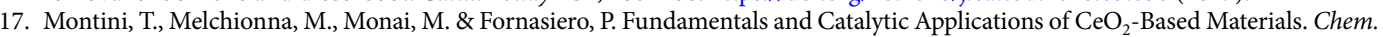
Rev. 116, 5987-6041. https://doi.org/10.1021/acs.chemrev.5b00603 (2016).

18. Nakayama, S., Kondo, S., Naka, T. \& Sakamoto, M. Carbon oxidation activity of complex oxides $\left(\mathrm{Part}_{1}\right) \mathrm{RE}_{2} \mathrm{CuO}{ }_{4}(\mathrm{RE}=\mathrm{La}-\mathrm{Gd})$ and $\mathrm{RE}_{2} \mathrm{Cu}_{2} \mathrm{O}_{5}$ (RE=Dy-Yb, Y). J. Ceram. Soc. Jpn. 119, 961-964. https://doi.org/10.2109/jcersj2.119.961 (2011).

19. Nakayama, S., Tokunaga, R., Shiomi, M. \& Naka, T. Carbon oxidation activity of complex oxides (Part 2) Characteristics of $\mathrm{La}_{0.9} \mathrm{Ag}_{0.1} \mathrm{FeO}_{\alpha}$ synthesized at low temperature using co-precipitation method, Journal of the Ceramic Society of Japan 121, 95-99 https://doi.org/10.2109/jcersj2.121.95(2013).

20. Nakayama, S. et al. Carbon oxidation characteristics of yttrium manganate catalyst prepared via urea decomposition. Ceram. Int. 43, 8538-8542. https://doi.org/10.1016/j.ceramint.2017.03.186 (2017).

21. Nakayama, S. \& Sakamoto, M. High oxidation activity of thallium oxide for carbon combustion. Thermochim. Acta 647, 81-85. https://doi.org/10.1016/j.tca.2016.12.005 (2017).

\section{Acknowledgements}

We would like to thank the direct contributions from the following students: Megumi Aibara, Yuri Akiduki, and Chiaki Umakoshi. Also, we would like to thank the Comprehensive Support Programs for Creation of Regional Innovation Science and Technology Incubation Program in Advanced Regions from Japan Science and Technology Agency (JST), the Grant of Steel Foundation for Environmental Protection Technology, and Editage (www. editage.com) for English language editing.

\section{Author contributions}

Corresponding author wrote all manuscript text and prepared all figures.

\section{Competing interests}

The author declares no competing interests.

\section{Additional information}

Correspondence and requests for materials should be addressed to S.N.

Reprints and permissions information is available at www.nature.com/reprints.

Publisher's note Springer Nature remains neutral with regard to jurisdictional claims in published maps and institutional affiliations.

Open Access This article is licensed under a Creative Commons Attribution 4.0 International License, which permits use, sharing, adaptation, distribution and reproduction in any medium or format, as long as you give appropriate credit to the original author(s) and the source, provide a link to the Creative Commons licence, and indicate if changes were made. The images or other third party material in this article are included in the article's Creative Commons licence, unless indicated otherwise in a credit line to the material. If material is not included in the article's Creative Commons licence and your intended use is not permitted by statutory regulation or exceeds the permitted use, you will need to obtain permission directly from the copyright holder. To view a copy of this licence, visit http://creativecommons.org/licenses/by/4.0/.

(C) The Author(s) 2021 